\title{
Faktor Risiko Yang Mempengaruhi Kejadian Skabies Di Indonesia : Literatur Review
}

\section{Factors Related To The Incidence Of Scabies In Indonesia: Literature Review}

\author{
Riyana Husna ${ }^{\text {a }}$, Tri Joko ${ }^{\mathrm{b}}$, Nurjazuli ${ }^{\mathrm{c}}$ \\ Magister Kesehatan Lingkungan, Universitas Diponegoro, Semarang ,Indonesia
}

\section{A B S T R A C T/A B S T R A K}

\begin{abstract}
Background: Scabies is a skin disease caused by infestation and sensitization of the Sarcoptes Scabiei v. Hominis mite that occurs in communities, groups, or families living in dense, low economy, and low knowledge. Maintenance of personal hygiene strongly determines the health status, where the individual consciously and on the personal initiative to maintain health dan prevent disease. Objective: Know more about the personal effect of hygiene on the incidence of scabies. Methods: Using literature studies from both national and international journals by summarizing the topic of discussion and comparing the results presented in the article. Results: There is a significant influence between personal hygiene habits, environmental sanitation, physical conditions of water, level of knowledge, density of room occupancy, age, sex, room ventilation area, bed, keteter installation, length of stay and water bacteriological examination. with the incidence of scabies. Conclusion: There is a significant relationship between personal hygiene, environmental sanitation, physical water conditions, level of knowledge, age, occupancy density. someone with an incidence of scabies
\end{abstract}

Keyword : scabies, personal hygiene, environment sanitation, room density, quality of water

\begin{abstract}
Latar Belakang: Skabies merupakan penyakit kulit yang disebabkan oleh infestasi dan sensitisasi terhadap tungau Sarcoptes scabiei. hominis yang terjadi pada komunitas, kelompok, atau keluarga yang tinggal dihunian padat, ekonomi rendah, dan pengetahuan rendah. Pemeliharaan personal hygiene sangat menentukan status kesehatan, dimana individu secara sadar dan atas inisiatif pribadi menjaga kesehatan dan mencegah terjadinya penyakit. Tujuan: Mengetahui lebih lanjut tentang pengaruh personal hygiene terhadap kejadian penyakit skabies. Metode: Menggunakan studi literatur dari jurnal baik nasional maupun internasioanl dengan cara meringkas topik pembahasan dan membandingkan hasil yang disajikan didalam artikel. Hasil: Ada pengaruh yang bermakna antara kebiasaan personal hygiene, sanitasi lingkungan, kondisi fisik air, tingkat pengetahuan, kepadatan hunian kamar, umur, jenis kelamin, luas ventilasi kamar, tempat tidur, pemasangan keteter, lama tinggal dan pemeriksaan bakteriologias air. dengan kejadian penyakit skabies. Kesimpulan: Terdapat hubungan signifikan antara personal hygiene,sanitasi lingkungan, kondisi fisik air,tingkat pengetahuan, umur,kepadatan hunian dan ventilasi kamar. seseorang dengan kejadian penyakit skabies.
\end{abstract}

Kata Kunci :Skabies, personal hygiene, sanitasi lingkungan, kepadatan hunia, kualitas fisik air.

\section{PENDAHULUAN}

\section{Menurut WHO (World Health}

Organization) terdapat sekitar 300 juta kasus skabies di dunia setiap tahunnya (2) Menurut sedangkan pada tahun 2014 WHO menyatakan angka kejadian skabies
130 juta orang di dunia ${ }^{(3)}$ International Alliance for the Control of Scabies (IACS) dalam Sahrudin (2017) kejadian skabies sangat beragam yaitu dari $0,3 \%$ menjadi 46\%. Penyakit skabies merupakan penyakit kulit yang endemis di wilayah 
beriklim tropis dan sub tropis, seperti Asia, Australia, Amerika Selatan, Karibia, Afrika .(4)

Sebuah studi epidemiologi di United Kingdom (UK) menunjukkan bahwa skabies lebih banyak terdapat di area perkotaan dan lebih sering terjadi pada musim dingin dibandingkan musim panas. ${ }^{(5)}$ Skabies masih menjadi masalah utama di banyak komunitas Aborigin di Australia, dimana berkaitan dengan tingkat kemiskinan dan kepadatan penduduk. Hasil survei didapatkan prevalensi skabies $25 \%$ pada orang dewasa, sedangkan prevalenssi tertinggi terjadi pada anak sekolah yaitu 30-65\%.(4) Menurut data KEMENKES RI prevalensi penyakit kulit di Indonesia di tahun 2012 adalah 8,46\% kemudian meningkat di tahun 2013 sebesar 9\% dan skabies menduduki urutan ketiga dari 12 penyakit kulit yang sering terjadi. Sebanyak 14 provinsi mempunyai prevalensi penyakit kulit diatas prevalensi nasional dan provinsi Sumatera Barat salah satunya. ${ }^{(6)}$

Beberapa faktor yang berkontribusi dalam kejadian skabies yaitu; kontak dengan penderita skabies, faktor sosial ekonomi, rendahnya tingkat personal hygiene dan kondisi lingkungan yang mendukung untuk berkembangnya skabies seperti kepadatan hunian, sanitasi yang tidak baik, dan akses air bersih yang sulit. ${ }^{(4)}{ }^{(7)}$ Personal hygiene atau biasa disebut dengan kebersihan diri adalah upaya untuk memelihara hidup sehat meliputi kehidupan bermasyarakat dan kebersihan beraktifitas. Personal Hygiene bisa disebut juga perawatan diri untuk mempertahankan kesehatan, baik secara fisik maupun psikologi. Kebersihan merupakan salah satu perilaku untuk mencegah timbulnya penyakit. Personal Hygiene dipengaruhi beberapa faktor diantaranya nilai sosial individu dan budaya, terutama pengetahuan dan persepsi mengenai kebersihan diri. Hal ini juga sejalan dengan penelitian yang dilakukan oleh Sekar (2011) menyatakan bahwa terdapat hubungan yang bermakna antara personal hygiene, status gizi dan sanitasi lingkungan terhadap kejadian skabies dengan nilai $\mathrm{p}$-value $<0.05$

Menurut penelitian Audhah et al (2012) di Pondok Pesantren Darul Hijah terdapat hubungan yang bermakna antara kepadatan hunian dengan kejadian skabies dengan $\mathrm{OR}=3,6$. Kepadatan hunian yang tinggi akan meningkatkan risiko kejadian skabies 3,6 kali dibandingkan dengan kepadatan hunian yang rendah. Hal ini dikarenakan kepadatan hunian yang tinggi, terutama pada kamar tidur menyebabkan kontak langsung antar santri menjadi tinggi sehingga memudahkan terjadinya penularan skabies dari satu ke santri lainnya ${ }^{(8)}$

Pengetahuan seseorang dapat mendukung terhindar dari suatu penyakit, terutama penyakit menular. Angka kejadian penyakit skabies meningkat pada kelompok masyarakat yang hidup dengan kondisi kebersihan diri dan lingkungan di bawah standar ${ }^{(10)}$.Hal ini disebabkan kurangnya pengetahuan masyarakat tentang skabies, faktor penyebab, cara penyebaran, hingga pencegahan ${ }^{(11)}$. Pada kelompok masyarakat yang mempunyai pengetahuan yang rendah terhadap perilaku hidup bersih dan sehat mereka mempunyai resiko terkena penyakit skabies (12) kali dibandingkan kelompok masyarakat yang mempunyai pengetahuan baik tentang perilaku hidup bersih dan sehat ${ }^{(10)}$. Pada tahun 2001, WHO menetapkan skabies sebagai penyakit yang berhubungan dengan air (water-related disease). Oleh karena itu, penyediaan air bersih yang cukup untuk masyarakat merupakan salah satu upaya pencegahan terhadap water-related disease. ${ }^{(9)}$

Berdasarkan uraian di atas dapat disimpulkan bahwa banyak faktor yang dapat mempengaruhi kejadian skabies, selain itu beberapa jurnal juga menyebutkan bahwa terdapat faktor air bersih, kepadatan hunian dan tingkat pengetahuan yang dapat mempengaruhi kejadian Skabies. Oleh karena itu peneliti ingin mengetahui lebih jauh faktor-faktor yang mempengaruhi kejadian Skabies dengan menggunakan studi 
literature dalam kurun waktu sepulu tahun terakhir ( 2010-2020)

\section{METODE}

Metode dalam penelitian ini adalah studi literature review, dimana peneliti mencari, menggabungkan inti sari serta menganalisis fakta dari beberapa sumber ilmiah yang akurat dan valid. Studi literature menyaji ulang materi yang diterbitkan sebelumnya, dan melaporkan fakta atau analisis baru. Tinjauan literature memberikan ringkasan berupa publikasi terbaik dan paling relevan. Kemudian membandingkan hasil yang disajikan dalam makalah .(13)

\section{Strategi Pencarian Literature ${ }^{(14)}$}

a. Data diperoleh dari database elektronik yakni Science Direct, ProQuest dan Google Scholar antara tahun 2010-2020 berupa artikel dan jurnal.

b. peneliti memilih sendiri artikel dan jurnal sesuai dengan judul peneliti yaitu "faktor resiko yang mempengaruhi kejadian skabies ".

c. Masing-masing dari 12 artikel yang dipilih untuk dibaca dengan cermat dari abstrak, tujuan, data analisis dari tujuan awal peneliti untuk mengumpulkan informasi tentang faktor resiko yang mempengaruhi kejadian skabies di indonesia .

d. Kriteria inklusi : adalah semua aspek yang harus ada dalam sebuah penelitian.

1. Artikel yang memiliki judul dan isi yang relevan dengan faktor resiko terhadap kejadian skabies.
2. Jurnal nasional dan internasional yang dipublikasi pada 2010-2020 dan bisa di akses full text.

3. Tipe artikel penelitian research articles (desain penelitian case control cross sectional dan deskriptif ).

Kriteria eksklusi :

1. Jurnal nasional dan internasional dari database yang berbeda dan tidak ada kaitan dengan variabel penelitian 2. Artikel penelitian diterbitkan sebelum tahun 2010 ataupun setelah tahun 2020 .

3. desain penelitian selain dari cross sectional, case control dan Deskriptif.

\section{Seleksi Studi dan Penilaian Kualitas}

Artikel yang masuk dalam kriteria inlklusi dianalisis, diekstraksi dan disintesis kemudian ditentukan evidancenya. Dari hasil pencarian literature review melalui database ProQuest, Science Direct dan Google scholar yang menggunakan keyword " Faktor resiko yang mempengaruhi kejadian skabies ".sehingga dilakukannya ekslusi dan didapatkan 12 jurnal yang dilakukan review. ${ }^{(15)}$

\section{Daftar artikel hasil pencarian}

Literature review yang digunakan dikelompokkan data -datanya yang sejenis sesuai dengan hasil yang dinilai untuk menjawad tujuan. Jurnal yang sudah sesuai dengan inklusi dikumpulkan menjadi satu dan diringkas meliputi nama peneliti, tahun terbit, judul, metode dan hasil penelitian

HASIL

Tabel 1. Daftar artikel hasil pencarian sebagai berikut :

\begin{tabular}{|c|c|c|c|c|c|c|}
\hline NO & Penulis & Tujuan & Desain & Sampel & Variabel & Hasil \\
\hline 1 & $\begin{array}{lrr}\text { Sari Yunita } & \text { M, } \\
\text { Rina Gustia } & \text { \& } \\
\text { Eliza } & \text { Anas, } 2015\end{array}$ & $\begin{array}{lr}\text { Untuk } & \text { menentukan } \\
\text { faktor } & \text { yang } \\
\text { berhubungan dengan } \\
\text { kejadian skabies di } \\
\text { wilayah } & \text { kerja } \\
\text { puskesmas } \\
\begin{array}{l}\text { Lubuk Buaya } \\
\text { Padang tahun }\end{array}\end{array}$ & $\begin{array}{l}\text { Desain case } \\
\text { control } \\
\text { dengan } \\
\text { matching }\end{array}$ & 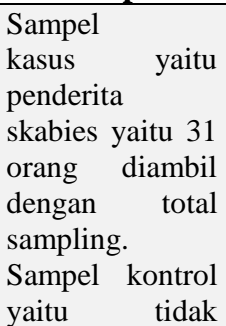 & $\begin{array}{l}\text { Personal } \\
\text { Hygiene, } \\
\text { kepadatan } \\
\text { hunian } \\
\text { kamar, luas } \\
\text { ventilasi } \\
\text { kamar, } \\
\text { ketersediaan } \\
\text { air bersih, }\end{array}$ & $\begin{array}{l}\text { Hasil penelitian } \\
\text { menunjukkan } \\
\text { terdapat hubungan } \\
\text { yang bermakna } \\
\text { antar personal } \\
\text { hygiene ( } \mathrm{p}=0,022, \\
\text { OR=5), } \\
\text { kepadatan hunian } \\
\text { kamar ( } \mathrm{p}=0,002,\end{array}$ \\
\hline
\end{tabular}




\begin{tabular}{|c|c|c|c|c|c|c|}
\hline & & & & $\begin{array}{l}\text { menderita } \\
\text { skabies } \\
\text { sebanyak } 31 \\
\text { orang dengan } \\
\text { perbandingan } \\
\text { 1:1 }\end{array}$ & status gizi. & 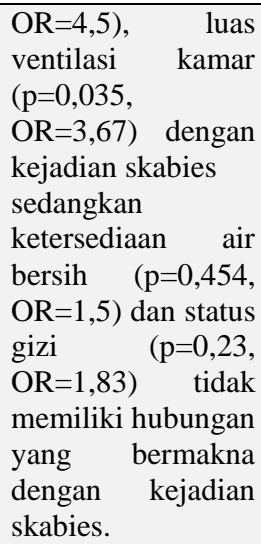 \\
\hline 2 & Budiman,.2013 & $\begin{array}{lr}\text { untuk } & \text { mengetahui } \\
\text { hubungan kebersihan } \\
\text { perorangan dan kondisi } \\
\text { fisik air dengan } \\
\text { kejadian scabies di } \\
\text { Desa } & \text { Wombo } \\
\text { Kecamatan Tanantovea } \\
\text { Kabupaten Donggala. }\end{array}$ & $\begin{array}{l}\text { Jenis } \\
\text { penelitian } \\
\text { yang } \\
\text { digunakan } \\
\text { adalah } \\
\text { survey } \\
\text { analitik } \\
\text { dengan } \\
\text { menggunak } \\
\text { an } \\
\text { pendekatan } \\
\text { case control }\end{array}$ & $\begin{array}{l}\text { Dengan jumlah } \\
\text { sampel semua } \\
\text { penderita } \\
\text { penyakit scabies } \\
\text { dan yang tidak } \\
\text { menderita } \\
\text { sebanyak } 32 \\
\text { kasus dan } 32 \\
\text { kontrol. Analisis } \\
\text { yang digunakan } \\
\text { adalah analisis } \\
\text { univariat dan } \\
\text { bivariat dengan } \\
\text { Uji Chi Square. }\end{array}$ & $\begin{array}{l}\text { Kebersihan } \\
\text { perorangan, } \\
\text { kondisi fisik } \\
\text { air. }\end{array}$ & $\begin{array}{l}\text { Hasil penelitian } \\
\text { menunjukkan } \\
\text { bahwa tidak ada } \\
\text { hubungan antara } \\
\text { kebersihan } \\
\text { perorangan } \\
\text { dengan kejadian } \\
\text { scabies dengan } \\
\text { nilai p= } 1,000> \\
0,05 \text { dan ada } \\
\text { hubungan antara } \\
\text { kondisi fisik air } \\
\text { dengan kejadian } \\
\text { scabies dengan } \\
\text { nilai p= } 0,000< \\
0,05 .\end{array}$ \\
\hline 3 & Yu-Chin Kao, 2011 & $\begin{array}{lr}\text { Menganalisis } & \text { faktor } \\
\text { risiko } & \text { penyebab } \\
\text { scabies } & \end{array}$ & $\begin{array}{l}\text { dengan } \\
\text { metode } \\
\text { case-control }\end{array}$ & \begin{tabular}{lr} 
Kami & \\
mendaftarkan 52 \\
pasien & kasus \\
kudis & dalam \\
penelitian & ini \\
dan & juga \\
memilih & 104 \\
pasien & kontrol \\
\multicolumn{2}{l}{ nonscabies }
\end{tabular} & $\begin{array}{l}\text { Pasien yang } \\
\text { tinggal di } \\
\text { panti jompo, } \\
\text { tempat tidur, } \\
\text { keteter. }\end{array}$ & $\begin{array}{l}\text { Penelitian kami } \\
\text { mengungkapkan } \\
\text { bahwa pasien yang } \\
\text { terbaring di tempat } \\
\text { tidur [rasio odds } \\
\text { (OR) 6,72,p < } \\
\text { 0,0001], tinggal di } \\
\text { panti jompo (OR } \\
9,89, \mathrm{p}<0,0001) \text {, } \\
\text { memiliki status } \\
\text { keparahan klinis } \\
\text { yang lebih tinggi } \\
\text { sebelum masuk } \\
\text { (OR 1,25, p < } \\
\text { 0,0001), dan } \\
\text { kateter } \\
\text { dimasukkan } \\
\text { (termasuk selang } \\
\text { nasogastrik, } \\
\text { kateter Foley, } \\
\text { Port-A, atau } \\
\text { kateter Hickman) } \\
\text { (OR 9.05, p < } \\
\text { 0,0001) secara } \\
\text { signifikan lebih } \\
\text { mungkin terkena } \\
\text { infeksi kudis. }\end{array}$ \\
\hline 4 & $\begin{array}{l}\text { Deka } \\
\text { Aprilianto,2015 }\end{array}$ & $\begin{array}{lr}\text { untuk } & \text { mengetahui } \\
\text { hubungan } & \text { personal } \\
\text { hygiene dan } & \text { sanitasi } \\
\text { kamar dengan kejadian } \\
\text { Scabies di } & \text { Pondok } \\
\text { Pesantren } & \mathrm{Al} \\
\end{array}$ & $\begin{array}{l}\text { Jenis } \\
\text { penelitian } \\
\text { ini adalah } \\
\text { survey } \\
\text { analitik } \\
\text { dengan } \\
\end{array}$ & \begin{tabular}{l}
\multicolumn{3}{l}{ Populasi } \\
penelitian ini \\
yaitu 535 santri \\
di Pondok \\
Pesantren Al \\
Musyaffa', \\
\end{tabular} & $\begin{array}{l}\text { Personal } \\
\text { Hygiene } \\
\text { terdiri dari : } \\
\text { Kebersihan } \\
\text { kulit,Kebersi } \\
\text { han rambut } \\
\end{array}$ & $\begin{array}{lr}\text { Hasil penelitian } \\
\text { yaitu } & \text { terdapat } \\
\text { hubungan antara } \\
\text { personal hygiene } \\
\text { dengan kejadian } \\
\text { scabies } & \text { (p-value } \\
\end{array}$ \\
\hline
\end{tabular}




\begin{tabular}{|c|c|c|c|c|c|}
\hline & Musyaffa' Kendal. & $\begin{array}{l}\text { rancangan } \\
\text { penelitian } \\
\text { cross } \\
\text { sectional } \\
\text { study }\end{array}$ & $\begin{array}{lr}\text { dengan } & \text { sampel } \\
\text { sebanyak } & 85 \\
\text { santri } & \end{array}$ & $\begin{array}{l}\text { Kebersihan } \\
\text { gigi } \\
\text { Kebersihan } \\
\text { telinga, } \\
\text { Kebersihan } \\
\text { tangan, kaki, } \\
\text { dan kuku, } \\
\text { Kebersihan } \\
\text { genitalia } \\
\text { dan sanitasi } \\
\text { Lingkungan } \\
\text { terdiri dari : } \\
\text { kondisi } \\
\text { kamar dan } \\
\text { kondisi } \\
\text { tempat tidur }\end{array}$ & 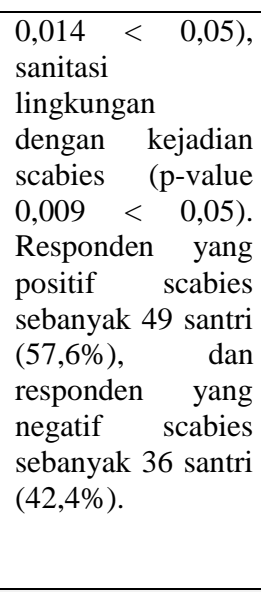 \\
\hline Desmawati,2015 & $\begin{array}{l}\text { Mengidentifikasi } \\
\text { hubunganpersonalhygi } \\
\text { enedan sanitasi } \\
\text { lingkungan } \\
\text { dengankejadian } \\
\text { Skabies pada Santri di } \\
\text { PondokPesantren Al- } \\
\text { Kautsar Pekanbaru }\end{array}$ & $\begin{array}{l}\text { Desain } \\
\text { Penelitian:J } \\
\text { enis } \\
\text { penelitian } \\
\text { ini adalah } \\
\text { deskriptif } \\
\text { korelasi } \\
\text { dengan } \\
\text { pendekatan } \\
\text { Cross } \\
\text { Sectional } \\
\text { (potong } \\
\text { silang) }\end{array}$ & $\begin{array}{l}\text { sampel yang } \\
\text { digunakanseban } \\
\text { yak 100 } \\
\text { responden yang } \\
\text { diambil } \\
\text { dari8kelasyang } \\
\text { ada diPondok } \\
\text { Pesantren AL- } \\
\text { Kautsar } \\
\text { Pekanbaru.Pada } \\
\text { penelitian ini } \\
\text { 100santri yang } \\
\text { akan diteliti } \\
\text { memiliki } \\
\text { kriteria, } \\
\text { yaitusiswa yang } \\
\text { telah } \\
\text { menempuh } \\
\text { pendidikanakad } \\
\text { emik minimal } \\
\text { satu } \\
\text { semesterdan } \\
\text { siswayang } \\
\text { bersedia } \\
\text { menjadi } \\
\text { responden }\end{array}$ & $\begin{array}{l}\text { Karakteristik } \\
\text { responden : } \\
\text { umur, lama } \\
\text { tinggal, } \\
\text { tingkat } \\
\text { pengetahuan } \\
\text { Persona } \\
\text { Hygiene, } \\
\text { kejadian } \\
\text { skabes, } \\
\text { kondisi } \\
\text { sanitasi } \\
\text { lingkungan. }\end{array}$ & $\begin{array}{l}\text { Berdasarkan hasil } \\
\text { statistik nilai p = } \\
0,781 \text { (nilai p> } \\
0,05 \text { ) tidak } \\
\text { menunjukkan } \\
\text { hubungan antara } \\
\text { kebersihan pribadi } \\
\text { dengan kejadian } \\
\text { skabies, serta hasil } \\
\text { statistik p value = } \\
0,306 \text { (p nilai> } \\
0,05) \text { tidak } \\
\text { menunjukkan } \\
\text { hubungan antara } \\
\text { sanitasi lingkungan } \\
\text { dengan kejadian } \\
\text { scabies. }\end{array}$ \\
\hline $\begin{array}{l}\text { Ahwath Riyadhy } \\
\text { Ridwan1, } 2017\end{array}$ & $\begin{array}{l}\text { Tujuan dari penelitian } \\
\text { yaitu untuk mengetahui } \\
\text { hubungan } \\
\text { pengetahuan, personal } \\
\text { hygiene, dan kepadatan } \\
\text { hunian terhadap gejala } \\
\text { penyakit skabies pada } \\
\text { santrin di Pondok } \\
\text { Pesantren Darul } \\
\text { Mukhlisinambaran } \\
\text { kota Kendari } \\
\text { 2017. }\end{array}$ & $\begin{array}{l}\text { Penelitian } \\
\text { yang di } \\
\text { lakukan } \\
\text { menggunak } \\
\text { an metode } \\
\text { analitik } \\
\text { observasion } \\
\text { al dengan } \\
\text { rancangan } \\
\text { pendekatan } \\
\text { cross } \\
\text { sectional } \\
\text { study. }\end{array}$ & $\begin{array}{l}\text { Populasi dalam } \\
\text { penelitian yaitu } \\
\text { seluruh santri di } \\
\text { Pondok } \\
\text { Pesantren Darul } \\
\text { Muhklisin } \\
\text { dengan } \\
\text { total santri } \\
\text { sebanyak } 272 \\
\text { orang. Sampel } \\
\text { dalam penelitian } \\
\text { yaitu sebanyak } \\
71 \quad \text { responden } \\
\text { yang diambil } \\
\text { dengan } \\
\text { metode } \\
\text { Proportionate } \\
\text { Stratified } \\
\text { random } \\
\text { sampling }\end{array}$ & $\begin{array}{l}\text { Tingkat } \\
\text { pengetahuan } \\
\text {, personal } \\
\text { Hygiene dan } \\
\text { kepadatan } \\
\text { hunian. }\end{array}$ & $\begin{array}{l}\text { Hasil yang didapat } \\
\text { dari penelitian } \\
\text { menyebutkan } \\
\text { bahwa tidak } \\
\text { ada hubungan yang } \\
\text { signifikan antara } \\
\text { pengetahuan } \\
\text { dengan kejadian } \\
\text { gejala skabies ( } \rho= \\
0,301) \text { adanya } \\
\text { hubungan } \\
\text { yang signifikan } \\
\text { antara personal } \\
\text { hygiyene terhadap } \\
\text { gejala skabies } \rho= \\
0,005) \text {, dan tidak } \\
\text { ada hubungan yang } \\
\text { signifikan antara } \\
\text { kepadatan hunian } \\
\text { dengan krjadian } \\
\text { gejala skabies ( } \rho= \\
0,232 \text { ). }\end{array}$ \\
\hline
\end{tabular}




\begin{tabular}{|c|c|c|c|c|c|}
\hline & & & & & $\begin{array}{l}\text { Kesimpulan dari } \\
\text { penelitian tidak } \\
\text { terdapat hubungan } \\
\text { pada variabel } \\
\text { pengetahuan dan } \\
\text { kepadatan hunian, } \\
\text { serta terdapat } \\
\text { hubungan pada } \\
\text { variable } \\
\text { personal hygiene } \\
\begin{array}{l}\text { dengan } \\
\text { skabies. }\end{array}\end{array}$ \\
\hline $\begin{array}{l}\text { Cindy } \\
\text { Mayrona, } 2018\end{array}$ & 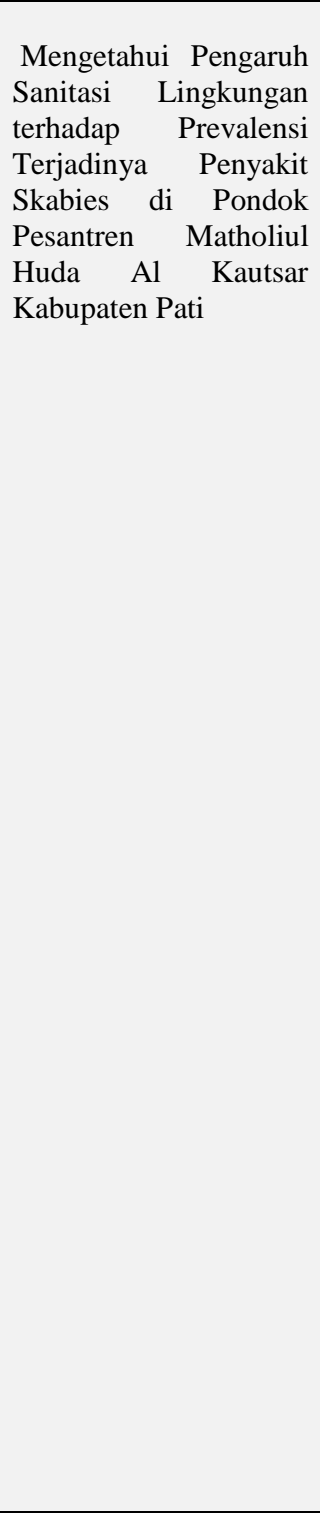 & $\begin{array}{l}\text { Penelitian } \\
\text { ini } \\
\text { menggunak } \\
\text { an } \\
\text { rancangan } \\
\text { penelitian } \\
\text { observasion } \\
\text { al dengan } \\
\text { pendekatan } \\
\text { cross } \\
\text { sectional }\end{array}$ & $\begin{array}{l}\text { Cara pemilihan } \\
\text { sampel } \\
\text { penelitian } \\
\text { dilakukan } \\
\text { dengan cara } \\
\text { purposive } \\
\text { sampling } \\
\text { berdasarkan } \\
\text { kriteria yang } \\
\text { telah ditetapkan } \\
\text { oleh peneliti. } \\
\text { didapatkan } \\
\text { minimal } 39 \\
\text { sampel. }\end{array}$ & $\begin{array}{l}\text { Variabel } \\
\text { bebas } \\
\text { penelitian ini } \\
\text { adalah yaitu } \\
\text { sanitasi } \\
\text { lingkungan } \\
\text { meliputi, } \\
\text { kamar } \\
\text { mandi, } \\
\text { kamar tidur, } \\
\text { kebersihan } \\
\text { lingkungan, } \\
\text { kebersihan } \\
\text { berwudhu, } \\
\text { dan } \\
\text { kebersihan } \\
\text { tempat } \\
\text { sholat. } \\
\text { sedangkan } \\
\text { variabel } \\
\text { terikat } \\
\text { penelitian ini } \\
\text { adalah } \\
\text { prevalensi } \\
\text { terjadinya } \\
\text { skabies } \\
\text { tingkat SMP } \\
\text { di Pondok } \\
\text { Pesantren } \\
\text { Matholiul } \\
\text { Huda Al } \\
\text { Kautsar } \\
\text { Kabupaten } \\
\text { Pati. }\end{array}$ & 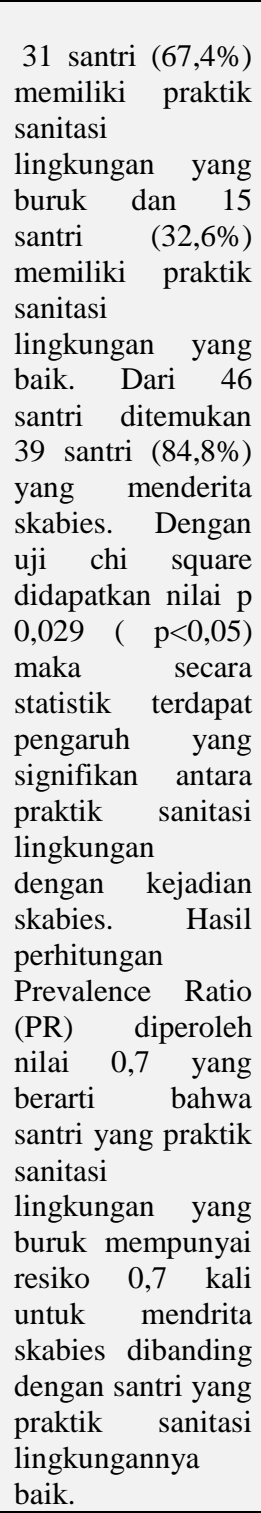 \\
\hline $\begin{array}{l}\text { Yeni Purwiyantini, } \\
2016\end{array}$ & $\begin{array}{l}\text { untuk menggambarkan } \\
\text { kualitas air konsumsi } \\
\text { penderita penyakit } \\
\text { kulit di pondok } \\
\text { pesantren Al Hikmah } \\
\text { desa Benda kecamatan } \\
\text { Sirampog kabupaten } \\
\text { Brebes propinsi Jawa } \\
\text { Tengah }\end{array}$ & $\begin{array}{l}\text { Jenis } \\
\text { penelitian } \\
\text { ini adalah } \\
\text { metode } \\
\text { penelitian } \\
\text { survei } \\
\text { deskriptif }\end{array}$ & $\begin{array}{lr}\text { Populasi } & \text { dalam } \\
\text { penelitian } & \text { ini } \\
\text { berjumlah } & 10 \\
\text { tempat } & \\
\text { pemandian dari } \\
\text { kurang lebih } 40 \\
\text { tempat } \\
\text { pemandian } \\
\text { penderita } \\
\text { penyakit kulit. } \\
\text { Teknik }\end{array}$ & $\begin{array}{l}\text { Variabel } \\
\text { dalam } \\
\text { penelitian ini } \\
\text { adalah } \\
\text { parameter } \\
\text { fisik air dan } \\
\text { bakteriologi. } \\
\text { Parameter } \\
\text { fisik air } \\
\text { terdiri dari } \\
\text { parameter }\end{array}$ & $\begin{array}{l}\text { Hasil penelitian } \\
\text { menunjukkan hasil } \\
\text { kualitas air } \\
\text { berdasarkan } \\
\text { parameter fisik } \\
\text { yang meliputi } \\
\text { warna, bau dan } \\
\text { kekeruhan } 40 \% \\
\text { memenuhi syarat } \\
\text { sedangkan } \\
\text { parameter }\end{array}$ \\
\hline
\end{tabular}


9 Ika julianti,2013 untuk perorangan dan kondisi yang fisik air dengan digunakan kejadian scabies di adalah wilayah kerja survey puskesmas Dolo analitik

analitik menggunak an pendekatan case control Kabupaten Sigi. pengambilan

sampel

menggunakan sampling yakni semua jumlah populasi di jadikan sampel yaitu sebanyak 10 pemandian. semua penderita penyakit scabies dan yang tidak menderita sebanyak 20

kasus dan 20

kontrol. Analisis

yang digunakan adalah analisis univariat dan bivariat dengan Uji Chi Square cara acak total Jumlah sampel

warna, bau, bakteriologis untuk rasa, total coliform 100

temperatur, \% tidak memenuhi $\mathrm{PH}, \quad \mathrm{TDS}$, syarat.

kekeruhan dan

bakteriologis air yaitu coliform.

Kebersihan perorangan dan kondisi fisik air bersih.

Hasil penelitian menunjukkan bahwa ada hubungan antara kebersihan perorangan dengan kejadian scabies dengan nilai $\mathrm{p}=$ $0,000<0,05$ dan ada

hubungan antara kondisi fisik air dengan kejadian scabies dengan nilai $\mathrm{p}=0,001<$ 0,05.).

10 Hamzah B, 2018 Penelitian ini Jenis dengan jumlah bertujuan untuk penelitian menganalisis hubungan yang kebiasaan mandi dan digunakan sampel sebanyak 43 responden. kebiasaan ganti observasion Teknik pakaian dengan al analitik kejadian skabies di dengan wilayah kerja rancangan Puskesmas Juntinyuat cross Kabupaten Indramayu sectional tahun 2018

\section{penarikan} sampel yang digunakan adalah Acidental Sampling. Data dikumpulkan dengan wawancara langsung kepada responden dan dianalisis secara univariat dan bivariat dengan menggunakan uji chi square.,

\section{Variabel}

dependen pada

penelitian ini

adalah

kejadian

skabies dan

variabel

independen

pada

penelitian ini

adalah

kebiasaan

mandi dan

kebiasaan

ganti

pakaian.

pakaian.

Has penelitian menunjukkan bahwa terdapat $\quad 58,2 \%$ responden yang menderita skabies, $39,5 \%$ responden yang memiliki kebiasaan ganti pakain kurang baik dan 46,5\% responden yang memiliki kebiasaan mandi yang kurang baik. Hasil uji statistik diperoleh ada hubungan antara kebiasaan mandi dengan kejadian skabies $(\mathrm{p}=0,007<0,05)$ dan ada hubungan antara kebiasaan ganti pakaian dengan kejadian skabies $(\mathrm{p}=0,009<0,05)$ wilayah kerja

Puskesmas

Juntinyuat

Kabupaten

Indramayu.

\begin{tabular}{|c|c|c|c|c|c|}
\hline $\begin{array}{l}\text { Suci Chairiya } \\
\text { Akmal, } 2012\end{array}$ & $\begin{array}{l}\text { bertujuan untuk } \\
\text { mengetahui kejadian } \\
\text { skabies siswa dan } \\
\text { kebiasaan siswa dalam } \\
\text { hal kebersihan diri. }\end{array}$ & $\begin{array}{l}\text { Penelitian } \\
\text { ini } \\
\text { merupakan } \\
\text { studi potong } \\
\text { lintang } \\
\text { (cross } \\
\text { sectional) }\end{array}$ & $\begin{array}{l}\text { Sampel } \\
\text { penelitian yaitu } \\
\text { semua santri di } \\
\text { Pondok } \\
\text { Pendidikan } \\
\text { Islam darul } \\
\text { Ulum Palarik }\end{array}$ & $\begin{array}{l}\text { Variabel } \\
\text { dependen } \\
\text { dari } \\
\text { penelitian ini } \\
\text { adalah } \\
\text { Skabies. } \\
\text { Sedangkan }\end{array}$ & $\begin{array}{l}\text { Hasil penelitian } \\
\text { menunjukkan bahwa } \\
\text { prevalensi skabies di } \\
\text { Pondok Pendidikan } \\
\text { Islam Darul Ulum, } \\
\text { Palarik, Air Pacah, }\end{array}$ \\
\hline
\end{tabular}




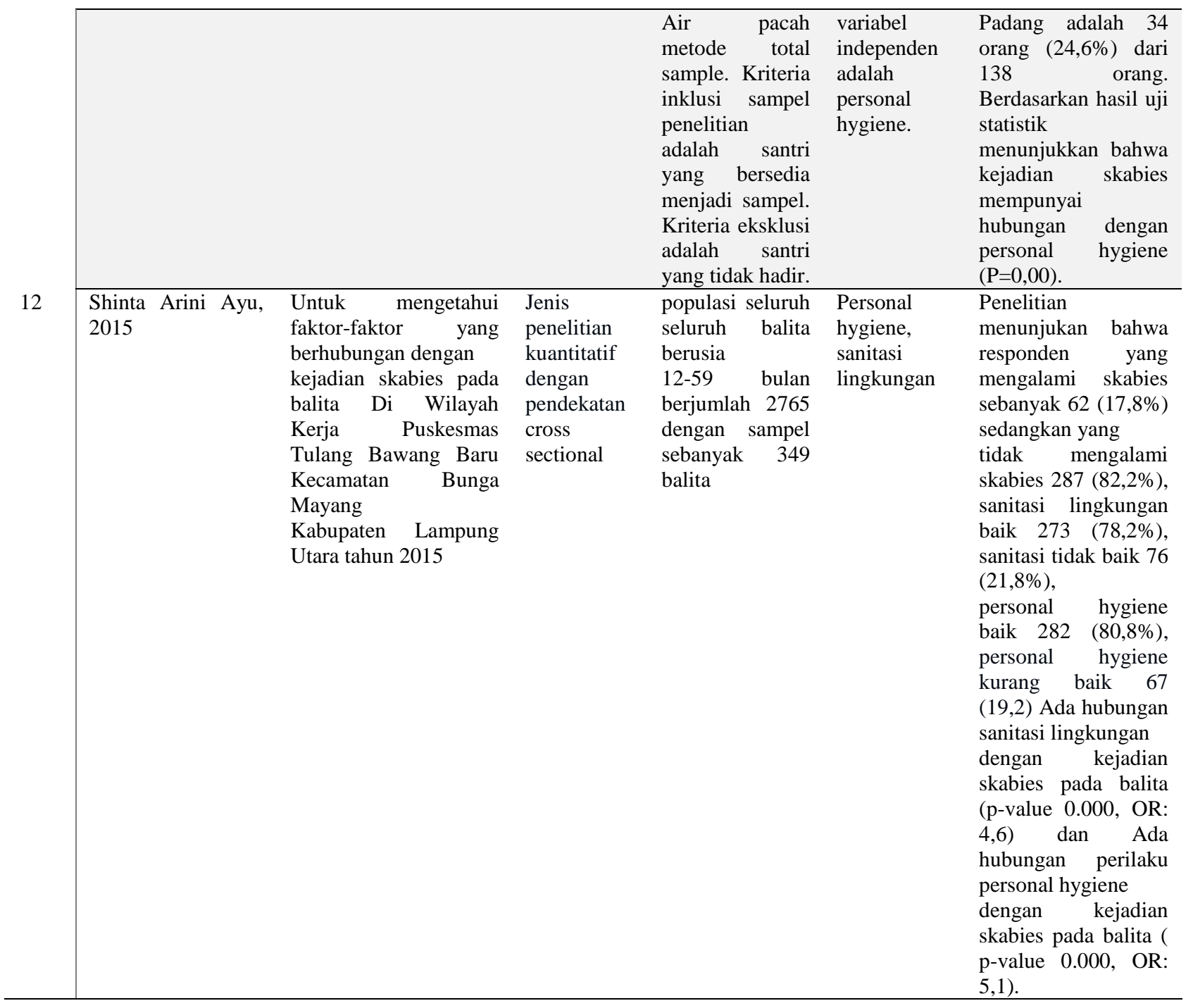

\section{PEMBAHASAN}

Dari tabel 1, dari 12 jurnal yang masuk dalam penelitian ditemukan 44 variabel secara keseluruhan dengan 33 variabel diantaranya bermakna secara statistik dengan kejadian skabies. Variabel yang berhubungan tersebut dilihat berdasarkan hasil uji statistic perartikel seperti personal hygiene, sanitasi lingkungan, kondisi fisik air , tingkat pengetahuan , kepadatan hunian kamar, umur, jenis kelamin, luas ventilasi kamar, tempat tidur, pemasangan keteter, lama tinggal dan pemeriksaan bakteriologias air.

Dari keseluruhan variabel tersebut terdapat faktor yang paling dominan berpengaruh terhadap kejadian skabies berdasarkan kesamaan hasil antar peneliti. Faktor-faktor dominan tersebut adalah personal hygiene, sanitasi linngkungan , kondisi fisik air bersih. Faktor yang tidak berpengaruh terhadap kejadian malaria ditemukan sebanyak 6 variabel diantaranya adalah ketersediaan air bersih, status gizi, personal hygiene, lama tinggal, pengetahuan dan kepadatan hunian kamar.

\section{Personal Hygiene}

Faktor yang sangat berperan terhadap timbulnya penyakit skabies yaitu personal hygiene. Personal hygiene menentukan status kesehatan seseorang secara sadar. Cara menjaga kesehatan tersebut meliputi menjaga kebersihan kulit, kebiasaan mencuci tangan dan kuku, frekuensi mengganti pakaian, pemakian handuk yang tidak bersamaan dengan orang lain, dan frekuensi mengganti sprei tempat tidur ${ }^{(10)}$. Kebersihan kulit individu yang buruk atau 
bermasalah akan mengakibatkan dampak fisik maupun psikososial. Kebersihan tangan dan kuku, karena Sebagian besar masyarakat menggunakan tangan untuk beraktifitas, makan dan lain sebagainya. Kebersihan pakaian perlu dijaga, dalam sehari pakaian yang berkeringat dan berlemak ini akan berbau busuk dan mengganggu sehingga perlu diganti. Infestasi tungau Sarcoptes scabiei selain kebiasaan jarang mengganti pakaian dengan pakaian bersih serta pinjam-meminjam pakaian. Pinjam-meminjam pakaian dapat mempermudah penularan skabies secara kontak tidak langsung ${ }^{(12)}$

Dalam keadaan ini masalah kesehatan yang akan muncul adalah pada kulit karena tubuh dalam keadaan lembab. Untuk itu perlu mengganti pakaian yang bersih setiap hari ${ }^{(1)}$. Sanitasi Total Berbasis Masyarakat (STBM) memiliki lima pilar yaitu stop buang air besarsembarangan, cuci tangan pakai sabun,pengelolaan air minum dan makanan rumah tangga, pengamanan sampah rumah tangga, danpengamanan limbah cair rumah tangga (16). Penularan skabies yang utama adalah kontak langsung dan tidak langsung. Penyakit skabies dapat ditularkan melalui kontak tidak langsung seperti handuk, perlengkapan tidur, dan sprei.

kebiasaan pemakaian alat mandi secara bergantian, dan kebiasaan tidur bersamaan. Selain kebiasaan tidur bersamaan, kondisi kamar tidur meliputi suhu dan kelembaban ruangan juga dapat berperan dalam berkembang biaknya tungau Sarcoptes scabiei. Suhu yang lebih lembab dan panas akan menyebabkan aktivitas tungau akan menjadi lebih tinggi.

\section{Sanitasi lingkungan}

Sanitasi lingkungan adalah suatu usaha pengendalian faktor-faktor yang dapat mengganggu atau mempengaruhi kesehatan dan kelangsungan hidup manusia. Kebersihan lingkungan dalam penelitian ini meliputi kebersihan kamar tidur, kebersihan tempat tidur.

Untuk mencapai lingkungan yang sehat, maka perlu adanya suatu usaha kesehatan. Menurut Notoatmodjo (2011: 169) usaha kesehatan lingkungan adalah suatu usaha untuk memperbaiki atau mengoptimumkan lingkungan hidup manusia agar merupakan media yang baik untuk terwujudnya kesehatan yang optimum bagi manusia yang hidup di dalamnya. Usaha perbaikan lingkungan ini dilakukan dari masa ke masa, dari usaha yang sederhana sampai yang modern.

Berdasarkan hasil uji statistik menyebutkan bahwa seseorang yang memiliki sanitasi lingkungan yang buruk akan lebih beresiko besar menderita skabies di bandingkan dengan orang yang memiliki sanitasi lingkungan baik. Maka dapat di ketahui bahwa Ada pengaruh antara praktik sanitasi lingkungan meliputi praktik kebersihan kamar mandi, kebersihan kamar tidur, kebersihan lingkungan, praktik berwudhu dan praktik kebersihan tempat sholat dengan kejadian skabies.(17)

\section{Kepadatan Hunian}

Faktor yang berperan pada tingginya prevalensi skabies di negara berkembang terkait dengan kemiskinan salah satunya adalah kepadatan hunian.Penyebaran tungau skabies akan lebih mudah terjadi pada penduduk yang hidup berkelompok atau padat penghuni pada suatu lingkungan seperti asrama, kelompok anak sekolah, antar anggota keluarga pada rumah yang padat penghuni bahkan antar warga di suatu perkampungan . Kepadatan hunian termasuk ke dalam salah satu syarat untuk kesehatan perumahan, dimana kepadatan hunian yang tinggi terutama pada kamar tidur akan memudahkan penularan penyakit skabies secara kontak langsung dari satu orang ke orang lain.

Hasil penelitian ini sejalan dengan penelitian yang dilakukan oleh Purba di Kecamatan Lubuk Pakam pada anak usia sekolah dimana sebagian besar responden yang menderita skabies tinggal di kamar dengan kepadatan hunian yang tidak memenuhi syarat. Hasil penelitian didapatkan dari 51 responden pada kelompok kasus, 37 orang $(72,5 \%)$ tinggal di kamar dengan kepadatan hunian tidak memenuhi syarat dan $14(27,5 \%)$ tinggal 
di kamar dengan kepadatan hunian memenuhi syarat

\section{Kondisi Fisik Air Bersih}

Kualitas air adalah merupakan suatu ukuran kondisi air dilihat dari karakteristik fisik, kimiawi, dan biologisnya. Kualitas air juga menunjukkan uku-ran kondisi air relatif terhadap kebutuhan biota air dan manusia. Kualitas air seringkali menjadi ukuran standar terhadap kondisi kesehatan ekosistem air dan kesehatan manusia terhadap air minum. Parameter pemeriksaan kualitas fisik air bersih yaitu: warna ,bau, rasa, temperatur, PH ,TDS ,Kekeruhan

Menurut Djuanda (2010) yang menyatakan bahwa air merupakan suatu sarana untuk meningkatkan derajat kesehatan masyarakat karena air merupakan salah satu media dari bebagai macam penu-laran penyakit. Melalui penyediaan air bersih baik dari segi kualitas maupun kuantitasnya disuatu daerah maka penyebaran penyakit menular diharapkan dapat ditekan seminimal mungkin. Kurangnya air bersih, khususnya untuk menjaga kebersihan diri dapat menimbulkan berbagai penyakit kulit karena jamur, bakteri, termasuk juga penyakit skabies.(18)

\section{KESIMPULAN}

Penelitian ini menyimpulkan bahwa terdapat banyak faktor yang dapat

\section{DAFTAR PUSTAKA}

1. Menaldi SLS, Bramono K IW. Ilmu penyakit kulit dan kelamin. edisi ke7. Jakarta Fak Kedokt Univ Indones. 2015;

2. (WHO) WHO. Water-related disease. 2009;36(12):5380-90. Tersedia pada: http://www.who.int/

3. WHO. Skin diseases in internationally adopted children: A retrospective analysis in a tertiary menyebabkan kejadian skabies. Faktor personal Hygiene, kondisi sanitasi lingkungan, kondisi fisik air bersih , umur, jenis kelamin, lama tinggal, kepadatan hunian kamar, luas ventilasi kamar,tingkat pengetahuan. Beberapa faktor yang dominan mempengaruhi kejadian skabies berdasarkan studi literature penelitian ini adalah personal hygiene, sanitasi lingkungan dan kondisi fisik air bersih.

\section{SARAN}

Pemeliharaan personal hygiene berarti tindakan memelihara kebersihan dan kesehatan diri seseorang untuk kesejahteraan fisik dan psikisnya. Banyak manfaat yang dapat diperolah yaitu seperti memperbaiki, merawat kebersihan diri, dan mencegah penyakit. Cara menjaga kesehatan tersebut dapat dilakukan dengan menjaga kebersihan kulit, kebiasaan mencuci tangan dan kuku, frekuensi mengganti pakaian, pemakaian handuk yang tidak bersamaan dengan orang lain, dan frekuensi mengganti sprei tempat tidur.Selain itu Tenaga kesehatan diharapakan dapat meningkatkan penyuluhan mengenai faktor-faktor yang mempengaruhi kejadian skabies.

\section{UCAPAN TERIMA KASIH}

Terima kasih kepada Bapak Tri Joko, dan Bapak Nurjazuli selaku Dosen pembimbing yang telah membantu dalam kegiatan penulisan Literatur Review ini.

care hospital in Tuscany, Italy, 2009-2016. Travel Med Infect Dis [Internet]. 2014;37(May):101679. Tersedia pada: https://doi.org/10.1016/j.tmaid.2020 .101679

4. Walton SF, Currie BJ. Problems in diagnosing scabies, a global disease in human and animal populations. Clin Microbiol Rev. 2007;20(2):268-79. 
5. Chosidow O. The New England Journal Of Medicine. 2006;16:354.

6. Kemenkes. Badan Penelitian dan Pengembangan Kesehatan Republik Indonesia.Riset Kesehatan Dasar (RISKESDAS). Badan Penelitian dan Pengembangan Kesehatan Kementrian Kesehatan RI(Internet). 2013.

7. Widiasih D. Epidemiologi zoonosis di Indonesia. YogyakartaGajah Mada Univ Press. 2012;

8. Desmawati, Dewi AP, Hasanah O. Hubungan Personal Hygiene Dan Sanitasi Lingkungan Dengan Kejadian Skabies Di Pondok Pesantren Al-Kautsar Pekanbaru. Univ Riau. 2015;2(1):628-37.

9. M SY, Gustia R, Anas E. Faktorfaktor yang Berhubungan dengan Kejadian Skabies di Wilayah Kerja Puskesmas Lubuk Buaya Kota Padang Tahun 2015. J Kesehat Andalas. 2018;7(1):51.

10. Rohmawati. Beberapa Faktor yang Berhubungan dengan Kejadian Skabies di Pondok Pesantren Nurul Hikmah Jatisawit Bumiayu Brebes,. UNDIP Semarang. 2010;

11. Audha, N,A., Umniyati, S.R.,\&Siswati A. Faktor Resiko Skabies Pada Siswa Pondok Pesantren. J Buski4(1). 2012;

12. Marga MP. Pengaruh Personal Hygiene Terhadap Kejadian Penyakit Skabies. J Ilm Kesehat Sandi Husada. 2020;12(2):773-8.
13. Marzali A-. Menulis Kajian Literatur. Vol. 1, ETNOSIA : Jurnal Etnografi Indo. 2017. 27 hal.

14. Beatrix E. L.Review. 2020;5.

15. Syahputra B. L. Review. Malaysian Palm Oil Counc [Internet]. 2020;21(1):1-9. Tersedia pada: http://mpoc.org.my/malaysianpalm-oil-industry/

16. Surya J. Sanitasi Total Berbasis Masyarakat (STBM Dengan Diare Pada Balita. J Ilm Kesehat Sandi Husada. 2019;10(2):281-4.

17. Afienna H. Hubungan Personal Hygiene dan Sanitasi Lingkungan dengan Kejadian Penyakit Scabies di Pondok Pesantren Marifatul Ulum Bringin Kabupaten Ngawi [Internet]. Vol. 1, Journal of Materials Processing Technology. 2018. Tersedia pada: http://dx.doi.org/10.1016/j.cirp.2016 $.06 .001 \% 0$ Ahttp://dx.doi.org/10.101 6/j.powtec.2016.12.055\%0Ahttps:// doi.org/10.1016/j.ijfatigue.2019.02. 006\%0Ahttps://doi.org/10.1016/j.m atlet.2019.04.024\%0Ahttps://doi.or g/10.1016/j.matlet.2019.127252\%0 Ahttp://dx.doi.o

18. Budiman, Hamidah FM. Hubungan Kebersihan Perorangan dan Kondisi Fisik Air dengan Kejadian Scabies di Desa Wombo Kecamatan Tanantovea Kabupaten Donggala. Kesehat Lingkung. 2015;1(3):1627. 